JOTE Volume 2 Nomor 1 Tahun 2020 Halaman 137-145 JOURNAL ON TEACHER EDUCATION

Research \& Learning in Faculty of Education

\title{
UPAYA MENINGKATKAN HAFALAN BACAAN DAN GERAKAN SHALAT DENGAN MEDIA AUDIO VISUAL (VIDEO) PADA ANAK USIA DINI DI DESA GERBANG SARI, KECAMATAN TAPUNG HILIR KABUPATEN KAMPAR
}

\author{
Siti Sahara ${ }^{1}$, Vitri Angraini Hardi ${ }^{2}$, Moh. Fauziddin ${ }^{3}$ \\ Program Studi Pendidikan Guru Pendidikan Anak Usia Dini, \\ Fakultas IImu Pendidikan, Universitas Pahlawan Tuanku Tambusai \\ Email : sitisahara876@gmail.com
}

\begin{abstract}
Abstrak
Penelitian ini bertujuan untuk mendeskripsikan penerapan metode demonstrasi dengan media audio visual untuk meningkatkan kemampuan bacaan dan gerakan sholat pada anak kelompok B TK Asmaul Husna. Hal ini dilakukan karena masih lemahnya kemampuan anak dalam pembelajaran sholat. Metode dan media yang digunakan untuk meningkatkan kemampuan tersebut adalah metode demonstrasi dengan media audio visual. Pengumpulan data dilakukan dengan mengadakan observasi, wawancara, dan dokumentasi. Hasil penelitian menunjukkan: 1) penerapan metode demonstrasi dengan media audio visual dilaksanakan dalam dua siklus. 2) hasil dari penerapan metode demonstrasi dengan media audio visual pada dalam pembelajaran sholat mengalami peningkatan yang signifikan. Peningkatan kemampuan praktek sholat terlihat dari kemampuan awal pra tindakan $42 \%$, meningkat menjadi $57 \%$ pada siklus I dan mengalami peningkatan menjadi $74 \%$ pada siklus II. Dengan demikian metode demonstrasi dengan media audio visual dapat meningkatkan kemampuan bacaan dan gerakan sholat untuk anak kelompok B TK Asmaul Husna.
\end{abstract}

Kata kunci: Kemampuan bacaan dan gerakan sholat, media audio visual

\begin{abstract}
This study aims to describe the application of the demonstration method with audio-visual media to improve reading skills and prayer movements in group $B$ children of Asmaul Husna Kindergarten. This is done because the child's ability to learn prayer is still weak. The method and media used to improve this capability is a demonstration method using audio-visual media. Data collection was carried out by conducting observations, interviews, and documentation. The results showed: 1) the application of the demonstration method with audio visual media was carried out in two cycles. 2) the results of the application of the demonstration method using audio-visual media in prayer learning have increased significantly. The increase in the ability to practice prayer can be seen from the initial pre-action ability of $42 \%$, increasing to $57 \%$ in cycle I and increasing to $74 \%$ in cycle II. Thus the demonstration method using audio-visual media can improve reading skills and prayer movements for group B children of Asmaul Husna Kindergarten.
\end{abstract}

Keywords: Readability and prayer movements, audio-visual media 


\section{PENDAHULUAN}

Pendidikan merupakan usaha sadar dan terencana yang dilakukan oleh seorang guru untuk mengembangkan dan membina segenap potensi anak didiknya secara optimal. Pendidikan tidak cukup hanya menekankan pada proses dan penyediaan fasilitas yang mengarah penguasaan ilmu pengetahuan teknologi, tetapi juga harus mengfasilitasi tumbuh kembangnya sikap dan pembiasaan dalam kehidupan sehari-hari.

Pelaksanaan shalat merupakan kemampuan yang harus dimiliki anak setelah lulus dari lembaga PAUD Asmaul Husna Gerbang Sari. Kenyataannya kemampuan praktek shalat selama ini anak-anak masih lemah, hal ini ditandai dengan (a) kurangnya lancarnya bacaan shalat, (b) kurangnya keterampilan dalam gerakan shalat, (c) kurang tertib dalam urutan gerakan shalat. Hal ini seperti yang terjadi di PAUD Asmaul Husna Gerbang Sari.

Dalam pembelajaran shalat di PAUD Asmaul Husna Gerbang Sari selama ini sudah menggunakan metode ceramah dan demontrasi. Seharusnya dengan metode tersebut anak didik sudah bisa menirukan gerakan shalat dengan terib dan benar, serta melafadzkan bacaan shalat dengan lancar. Namun dalam pembelajaran shalat anak didik terlihat kurang memperhatikan, sebagian anak asyik bermain sendiri, berbicara dengan teman sebelahnya, bahkan ada anak yang berjalan-jalan di dalam kelas.

Meskipun penelitian terdahulu telah memberikan kontribusi besar terhadap masalah yang ada bagi perbaikan tetapi masih menyisakan banyak persoalan. Persoalan umum dari ketiga penelitian adalah kejanggalan hasil peningkatan yang dicapai dari pra tindakan yang semula $34 \%-40 \%$ meningkat menjadi $80 \%$ - 90\%. Hasil tersebut terlalu drastis karena terjadi peningkatan lebih dari $50 \%$, dalam dua siklus yang waktunya tidak terlalu lama. Hal itu tidak mungkin terjadi karena pembelajaran adalah proses yang tidak bis instan. Anak didik membutuhkan waktu yang cukup untuk menerima, memahami dan mencerna suatu pengetahuan atau keterampilan tertentu. Persoalan khusus penelitian Masytthoterletak pada beliau tidak mencantumkan metode apa yang digunakan dalam penelitiannya. Persoalan khusus penelitian Yuliana adalah dalam penggunaan media gambar, gambar yang digunakan bersifat statis, tidak bergerak, dan ukurannya terbatas sehingga dibutuhkan ganbar yang banyak dan bervariasi. Media gambar jika digunakan terus menerus dapat menimbulkan kebosanan dan kejenuhan pada anak didik. Ketidakmampuan atau keterbatasan guru untuk menggambar dengan baik juga menjadi masalah tersendiri. Singkatnya waktu pembelajaran serta banyaknya jumlah anak didik dalam satu kelompok juga menjadi masalah, ukuran gambar yang terbatas menyebabkan anak yang dibelakang cenderung tidak mendapat porsi yang cukup untuk melihat gambar secara jelas.

Solusi baru yang dimaksud dalam penelitian ini adalah metode demontrasi dengan media audio visual (video) upaya meningkatkan kemampuan hafalan bacaan dan gerakan shalat di kelompok B TK Asmaul Husna Gerbang Sari, adalah ide kreatif yang bertumpu pada teori ibadah shalat (Syaiful Bahri Djamarah,2010:120). Metode dan media pembelajaran (Hasbi Asy-Syidiqi, 1979: 39) demonstrasi dipilih karena metode ini paling tepat untuk pembelajaran shalat. 
Media audio visual peneliti yakin anak didik akan lebih tertarik, bersemangat dan minat anak akan tumbuh sehingga tujuan pembelajaran akan tercapai. Metode demonstrasi dengan media audio visual akan diaktualisasikan dalam tindakan tindakan cemerlang sepanjang proses penelitian ini. Tindakan cemerlang yang akan dilakukan dalam penelitian ini adalah meningkatkan kemampuan menghafal bacaan dan gerakan shalat melalui metode demonstrasi dengan menggunakan media audio visual pada kelompok B TK Asmaul Husna Gerbang Sari.

Berdasarkan latar belakang diatas, maka dibutuhkan metode demonstrasi dengan media audio visual untuk upaya meningkatkan kemampuan anak didik dalam menghafal bacaan shalat dan praktek shalat di kelompok B TK Asmaul Husna Gerbang Sari. Dalam tulisan ini akan dijelaskan besaran peningkatan kemampuan menghafal bacaan shalat dan gerakan shalat melalui metode demonstrasi dengan media audio visual di kelompok B TK Asmaul Husna Gerbang Sari. Selanjutnya akan dijelaskan pengembangan atau kreasi metode demonstrasi dengan media audio visual.

\section{Kemampuan Bacaan Sholat Dan Gerakan Sholat}

Menurut Bloom, kemampuan adalah perilaku kognitif berkenan dengan pikiran, nalar individu dan hasil berpikir baik berupa kemampuan berpikir, persepsi, pengetahuan, pemahaman, gagasan. Sholat secara etimologis, sholat berarti doa secara terminologis.ahli fiqih mengartikan secara lahir berarti beberapa ucapan dan perbuatan yang dimulai dengan takbir dan di akhiri salam, yang dengannya kita beribadah kepada Allah menurut syarat yang telah ditentukan. Dari beberapa pengertian di atas dapat disimpulkan bahwa sholat merupakan ibadah kepada Allah berupa perkataan dengan perbuatan yang diawali takbir dan diakhiri dengan salam dengan syarat dan rukun yang telah ditentukan syara'

\section{Media Audio Visual}

Kata media " berasal dari bahasa latin dan merupakan bentuk jamak dari kata "medium" yang secara harfiah berarti "perantara atau pengantar". Dengan demikian media merupakan penyalur informasi atau penyalur pesan. (Syaiful Bahri Djamarah, 2010:120) Bila media adalah sumber belajar, maka secara luas media dapat diartikan dengan manusia, benda ataupun peristiwa yang memungkinkan anak didik memperoleh pengetahuan dan keterampilan, dapat merangsang pikiran, perasaan, dan kemauan anak didik sehingga dapat mendorong terjadinya proses belajar pada dirinya. Penggunaan media secara kreatif akan memungkinkan anak didik untuk belajar lebih baik dan dapat meningkatkan performan mereka sesuai dengan tujuan yang ingin dicapai. Pengertian audio visual menurut kamus Besar Bahasa Indonesia, audio bersifat dapat didengar. Visual bersifat dapat dilihat dengan indra penglihatan. Audio visual bersifat dapat didengar dan dilihat.

Macam-macam media, dilihat dari jenisnya dibagi menjadi tiga yaitu media auditif, media yang hanya mengandalkan kemampuan suara saja, seperti radio, casette recorder, piringan hitam, media visual, media yang hanya mengandalkan indra penglihatan. Media ini ada yang menampilkan gambar diam seperti film rangkai, slide foto, gambar, dan menampilkan gambar diam seperti 
film bisu dan film kartun, dan Media audiovisual, yaitu media yang mempunyai unsur suara dan unsur gambar. Jenis ini mempunyai kemampuan yang lebih baik karena meliputi kedua jenis media yang sangat efektif dalam pembelajaran. Media audiovisual memiliki manfaat lebih dari media yang lain yaitu menarik pikiran anak. Memperjelas isi materi pembelajaran, mempermudah konsep yang kompleks, dan abstrak menjadi lebih sederhana, konkrit dan mudah dipahami, dan meningkatkan tepat guna dan efisiensi sehingga mempertinggi daya serap anak terhadap materi pelajaran.

Berdasarkan seluruh kajian teori diatas yang di maksud meningkatkan kemampuan menghafal bacaan dan gerakan sholat dengan media audiovisual maka dapat meningkatkan kemampuan anak untuk melakukan perbuatan dan perkataan yang dimulai dari takbiratul ikhrom sampai salam menurut syarat dan rukun yang sudah ditentukan pada kelompok B TK Asmaul Husna Gerbang Sari.

\section{METODE}

Penelitian ini merupakan Penelitian Tindakan Kelas (Classroom Action Research) dengan menggunakan pendekatan deskriptif kuantitatif, yang bertujuan untuk mendeskripsikan kemampuan anak didik di kelas utamanya deskripsi meningkatkan kemampuan menghafal bacaan sholat dan gerakan sholat pada anak didik di TK Asmaul Husna Gerbang Sari, di kelompok B, terdiri dari 10 anak laki-laki dan 11 anak perempuan. Penelitian ini merupakan penelitian kolaborasi antara guru kelas dengan peneliti.

Secara umum, karakteristik anak-anak di kelas ini dapat dikelompokkan menjadi tiga macam. Pertama, kelompok anak yang tertib, fokus dan sangat memperhatikan setiap materi yang diajarkan guru. Kedua, kelompok anak yang aktif, banyak bergerak,bermain sendiri, berbicara dengan teman sebelah, dan jalan-jalan. Ketiga, kelompok anak yang pasif, pendiam, dan tidak mau jika diminta guru untuk action. Dalam konteks penelitian ini, sebagian besar anak anak mengalami kesulitan dalam memahami dan menerima pembelajaran praktek sholat.

PTK ini mengambil yang dikembangkan oleh Kemmis dan Mc. Taggart yang merupakan pengembangan dari konsep Kurt Lewin yang terdiri dari empat komponen yaitu, perencanaan, tindakan, pengamatan dan refleksi, kemudian dikembangkan oleh Kemmis dan Mc. Taggart. Kemmis dan Mc Taggart menyatukan komponen tindakan dan pengamatan sebagai satu kesatuan. Hasil dari pengamatan ini dijadikan dasar langkah berikutnya yaitu refleksi. Dari refleksi disusun sebuah modifikasi yang diaktualisasikan dalam bentuk rangkaian tindakan dan pengamatan, begitu seterusnya (Lexy).

1. Perencanaan: a) membuat skenario pembelajaran yang meliputi Rencana Pelaksanaan Pembelajaran Harian (RPPH) materi sholat melalui metode demonstrasi dengan media audiovisual, b) membuat instrumen/lembar observasi untuk melihat kondisi pembelajaran shalat, c) menyiapkan alat peraga yang diperlukan meningkatkan kemampuan praktek shalat anak didik yaitu perangkat audio visual yang terdiri dari: laptop, LCD, dan screen, d) mendesain alat evaluasi untuk mengetahui kemampuan menghapal bacaan dan gerakan shalat anak didik 
2. Tindakan Siklus. Pada tahap ini peneliti bersama guru mendesain pembelajaran sholat melalui metode demonstrasi dengan media audio visual. Selama pembelajaran berlangsung peneliti dalam mengajar menggunakan RPPH yang telah disusun dengan pertimbangan dari guru kelas. Sedangkan guru kelas sebagai pengamat dimana lembar observasi sudah disiapkan oleh peneliti.

3. Observasi/Pengamatan siklus. Peneliti perlu mengamati beberapa hal antara lain: proses tindakan, pengaruh tindakan (baik yang disengaja maupun yang tidak disengaja), keadaan dan kendala tindakan, serta persoalan lain yang timbul pada saat penerapan dengan media audio visual. Pengamatan dilakukan oleh guru sedangkan peneliti sebagai pelaksana pembelajaran. Pengamatan dilakukan selama kegiatan pembelajaran berlangsung dengan menggunakan lembar observasi yang sudah disiapkan peneliti. Lembar observasi digunakan untuk mengetahui jalannya pembelajaran sholat melalui media audio visual.

4. Refleksi siklus. Pada tahap ini peneliti mengumpulkan dan mengindentifikasi data yang telah diperoleh, yaitu meliputi lembar observasi dan wawancara serta catatan dari guru. Kemudian peneliti melakukan refleksi. Pelaksanaan refleksi dilakukan antara peneliti dengan guru yang bersangkutan. Diskusi dilakukan untuk mengevaluasi hasil yang telah dilakukan yaitu dengan cara melakukan penilaian terhadap proses selama pembelajaran berlangsung. Masalah yang muncul dan berkaitan dengan hal-hal yang dilakukan setelah melakukan refleksi kemudian peneliti membuat rencana untuk siklus selanjutnya.

5. Tindakan pada siklus 2 dilakukan berdasarkan perencanaan dan perbaikan dari hasil refleksi siklus sebelumnya, kemudian dilakukan refleksi untuk melihat sejauh mana perubahan yang terjadi melalui tindakan kedua.

\section{HASIL DAN PEMBAHASAN}

\section{Pra Tindakan}

Sebelum melakukan penelitian, terlebih dahulu dilaksanakan observasi pra tindakan untuk mengukur seberapa tingkat kemampuan anak didik kelompok B TK Asmaul Husna Gerbang Sari. Selain itu observasi pra tindakan dilakukan untuk mencari titik masalah, solusi yang akan digunakan serta metode dan media yang akan diterapkan. Hasil pra tindakan ini juga sebagai acuan berapa persen peningkatan yang ingin dicapai setelah diadakan tindakan. Observasi pra tindakan ini dilaksanakan hari Jumat tanggal 17 Juli 2020. Dari observasi pra tindakan yang dilakukan menunjukkan hasil kegiatan belajar materi shalat meliputi aspek 1) Menirukan gerakan shalat dengan benar, 2) Melafadzkan bacaan shalat dengan lancar, 3) Menirukan gerakan shalat dengan tertib. Dapat dilihat pada aspek menirukan gerakan sholat dan melafadzkan bacaan sholat 6 orang anak (28,57\%) yang di kategorikan mulai berkembang, dan 15 orang anak $(71,43 \%)$ yaang di kategorikan belum berkembang.

Dari data tersebut dapat diambil rata-rata kemampuan praktek shalat dan bacaan shalat anak didik kelompok B TK Asmaul Husna Gerbang Sari secara keseluruhan sebesar 44\%. Berdasarkan hasil tersebut peneliti bersama 
kolaborator sepakat penelitian berhasil atau dapat dihentikan apabila rata - rata tingkat kemampuan praktek shalat dan bacaan shalat sudah mencapai angka 65$75 \%$.

\section{Siklus I}

a. Perencanaan. Rencana tindakan siklus I antara lain: 1) Menentukan hari pelaksanaan siklus 1, 2) Membuat Rencana Pelaksanaan Pembelajaran (RPPH) materi shalat, 3) Menata ruang kelas, 4) Mempersiapkan sarana dan media pembelajaran audio visual yang akan digunakan pada saat pembelajaran, dan 5) Mempersiapkan lembar observasi yang akan digunakan pada saat pembelajaran.

b. Pelaksanaan Tindakan Siklus I sebanyak 2 kali pertemuan yaitu pada tanggal 17 dan 22 Mei 2020. Kegiatannya meliputi: 1) membuka dengan salam dilanjutkan dengan doa, 2) memberikan pertanyaan seputar kegiatan ibadah yang dilakukan anak didik, 3) menghidupkan laptop beserta sound diaktifkan dan dihubungkan dengan proyektor dan menayangkan video. 4) memberikan penjelasan setelah video selesai diputar, 5) video diputar lagi dan anak - anak menirukan gerakan shalat dan bacaan shalat. Kegiatan tersebut diulang sampai 2 kali.

c. Pengamatan dilakukan oleh guru sedangkan peneliti sebagai pelaksana pembelajaran. Pengamatan dilakukan selama kegiatan pembelajaran berlangsung dengan menggunakan lembar observasi yang sudah disiapkan oleh peneliti. Lembar obsevasi digunakan untuk mengetahui jalannya pembelajaran shalat dengan media audio visual.

d. Refleksi siklus 1, peneliti mengumpulkan dan mengidentifikasi data yang telah diperoleh, yaitu meliputi lembar observasi dan wawancara serta catatan dari guru. Kemudian peneliti melakukan refleksi. Pelaksanaan refleksi dilakukan antara peneliti dengan guru yang bersangkutan. Diskusi dilakukan untuk mengevaluasi hasil yang telah dilakukan yaitu dengan cara melakukan penilaian terhadap proses selama pembelajaran berlangsung. Masalah yang muncul dan berkaitan dengan hal-hal yang dilakukan setelah melakukan refleksi kemudian peneliti membuat rencana untuk siklus selanjutnya.

Berdasarkan hasil pengamatan kegiatan siklus 1, telah terjadi peningkatan kemampuan praktek shalat dan bacaan shalat. Hal itu dapat dilihat dari ketiga aspek yang diamati terjadi peningkatan. Namun hasil peningkatan tersebut belum memenuhi kriteria yang peneliti harapkan, belum mencapai ketuntasan minimal. Menurut pengamatan peneliti hasil kurang maksimal karena strategi pembelajaran klasikal, sehingga anak didik dalam mengamati gambar yang ditayangkan menjadi kurang fokus. Sebagian anak masih berbicara dengan teman sebelah atau bercanda dengan teman. Penayangan video yang hanya 2 kali juga dirasakan kurang. Untuk itu peneliti merencanakan mengubah strategi pembelajaran dari klasikal menjadi kelompok, dan menambah jumlah penayangan video menjadi 3 kali tayang. 


\section{Siklus II}

a. Perencanaan. Rencana tindakan siklus 1 antara lain, 1) Menentukan hari pelaksanaan siklus 2, 2) Membuat Rencana Pelaksanaan Pembelajaran Harian (RPPH) materi shalat, 3) Menata ruang kelas, 4) Membagi anak didik menjadi 2 kelompok, masing-masing kelompok 10 anak, 5) Mempersiapkan sarana dan media pembelajaran audio visual yang akan digunakan pada saat pembelajaran yaitu laptop, CD, speaker, 6) Mempersiapkan lembar observasi yang akan digunakan pembelajaran.

b. Pelaksanaan, Tindakan Siklus II sebanyak 2 kali pertemuan yaitu pada tanggal 23 dan 24 Juli 2020. Pelaksanaan Tindakan Siklus II meliputi; 1) membuka kegiatan dengan salam, dilanjutkan doa, 2) memulai pembelajaran dengan pertanyaan seputar kegiatan dan apresiasi anak didik terhadap tayangan video pada siklus 1, 3) menghidupkan laptop beserta sound di aktifkan dan dihubungkan dengan proyektor dan memutar video lanjutan, 4) memberikan penjelasan setelah video selesai diputar secara klasikal, 5) video diputar lagi dan anak-anak menirukan gerakan sholat dan bacaan sholat, 6) kegiatan tersebut diulang sampai 3 kali.

c. Pengamatan dilakukan oleh guru sedangkan peneliti sebagai pelaksana pembelajaran. Pengamatan dilakukan selama kegiatan pembelajaran berlangsung dengan menggunakan lembar observasi yang sudah disiapkan oleh peneliti. Lembar observasi digunakan untuk mengetahui jalannya pembelajaran shalat melalui media audio visual.

d. Refleksi. Pada tahap ini, peneliti mengumpulkan dan mengidentifikasi data yang telah diperoleh, yaitu meliputi lembar observasi dan wawancara serta catatan dari guru. Kemudian peneliti dengan guru yang bersangkutan. Diskusi dilakukan untuk mengevaluasi hasil yang telah dilakukan yaitu dengan cara melakukan penilaian terhadap proses selama pembelajaran berlangsung. Masalah yang muncul dan berkaitan dengan hal - hal yang dilakukan setelah melakukan refleksi kemudian peneliti membuat rencana untuk siklus selanjutnya.

Berdasarkan hasil pengamatan kegiatan siklus II, telah terjadi peningkatan kemampuan praktek shalat dan bacaan shalat. Hal itu dapat dilihat dari ketiga sapek yang diamati terjadi peningkatan. Namun hasil peningkatan tersebut sudah memenuhi kriteria yang peneliti harapkan. Kriteria penilaian kemampuan praktek shalat beserta bacaan shalat sudah mencapai indikator yang ditentukan yakni antara 65\% - 75\%, bahkan sudah melebihi kriteria. Berdasarkan refleksi diatas, indikator keberhasilan sudah tercapai sehingga siklus dinyatakan berhenti.

Peningkatan kemampuan praktek shalat dan bacaan shalat anak didik kelompok B TK Asmaul Husna Gerbang Sari dapat di lihat dalam tabel berikut ini: 


\begin{tabular}{|c|c|c|c|c|c|c|}
\hline No & Tingkat & \multirow{2}{*}{ Kriteria } & \multicolumn{2}{|c|}{ Siklus I } & \multicolumn{2}{c|}{ Siklus II } \\
\cline { 4 - 7 } & Keberhasilan & & F & Persen(\%) & F & Persen(\%) \\
\hline 1. & $>80 \%$ & BSB & 0 & $0 \%$ & 9 & 42,86 \\
\hline 2. & $60 \%-79 \%$ & BSH & 4 & 19,05 & 6 & 28,57 \\
\hline 3. & $40 \%-59 \%$ & MB & 17 & 80,95 & 6 & 28,57 \\
\hline 4. & $20 \%-39 \%$ & BB & 0 & 0 & 0 & 0 \\
\hline \multicolumn{2}{|c|}{ Jumlah } & $\mathbf{2 1}$ & $\mathbf{1 0 0}$ & $\mathbf{2 1}$ & $\mathbf{1 0 0}$ \\
\hline
\end{tabular}

Berdasarkan tabel diatas di dapat beberapa hal yaitu: siklus I, Berkembang Sesuai Harapan 4 anak (19,05\%), dan Mulai Berkembang 17 anak (80,95\%). Pada Siklus II, Berkembang Sangat Baik 9 anak (42,86\%), Berkembang Sesuai Harapan 6 anak (28,57\%), Mulai Berkembang 6 anak $(28,57 \%)$.

Dari data tersebut dapat diambil kesimpulan bahwa dengan media audio visual terbukti mampu meningkatkan kemampuan bacaan shalat dan gerakan shalat anak didik kelompok B TK Asmaul Husna Gerbang Sari.

Cara penerapan yang digunakan pada siklus 1 adalah dengan klasikal dan cara penerapan pada siklus 2 dengan berkelompok. Dari dua cara tersebut dapat dilihat bahwa cara berkelompok lebih efektif dari pada cara klasikal. Pada cara berkelompok anak-anak menjadi lebih fokus memperhatikan tayangan video, dan berarti lebih meningkatkan daya serap anak. Berdasarkan penjelasan di atas dapat ditarik kesimpulan bahwa cara penerapan yang paling tepat untuk menerapkan dengan media audio visual (video) pada kelompok B TK Asmaul Husna Gerbang Sari adalah dengan cara membentuk kelompok kecil.

\section{SIMPULAN}

Penerapan pembelajaran shalat melalui media audio visual di TK Asmaul Husna Gerbang Sari berjalan dengan baik, karena dapat meningkatkan kemampuan praktek shalat. Hal ini terbukti dengan adanya anak didik yang mampu melaksanakan praktek shalat beserta bacaan shalat dengan benar.

Penerapan dengan media audio visual pada kelompok B TK Asmaul Husna Gerbang Sari, dapat meningkat kemampuan praktek shalat beserta bacaan shalat anak-anak. Kemampuan praktek shalat beserta bacaan shalat anak kelompok B TK Asmaul Husna Gerbang Sari meningkat dari obsevasi pra tindakan $44 \%$, setelah melaksanakan tindakan siklus 1 menjadi $67 \%$, dan pada siklus II, mengalami peningkatan menjadi $80 \%$. Dengan demikian media audio visual dapat meningkatkan kemampuan praktek shalat anak kelompok B TK Asmaul Husna Gerbang Sari. Hasil penelitian menunjukkan bahwa pembelajaran shalat beserta bacaan shalat dengan media audio visual membuat anak didik memperhatikan tayangan video tersebut sambil menirukan setiap gerakan dan bacaan shalat, peneliti juga memberi penjelasan serta membenarkan anak dalam melakukan gerakan shalat dengan benar. Anak didik melakukan kegiatan dengan senang, semangat, serta melakukan dengan sungguh-sungguh. 


\section{DAFTAR PUSTAKA}

Abdul Majiddan Dian Andayani, Pendidikan Agama Islam Berbasis Kompetensi, PT Remaja Rosdakarya, Jakarta, 2006

Abdullah Gymnastiar, Shalat Best of The Best, (Bandung: PT. Senibudaya Sejahtera Offset, 2005)

Abu Bakar Jabir Al-Jazairi, Ensiklopedi Muslim (Jakarta: PT. Darul Falah

Ahmad Tafsir, Metodologi Pendidikan, Rineka Cipta, Bandung, 1999

Amani Ar-Ramadi, Pendidikan Cinta Untuk Anak, PT.Aqwam Media Profetika

Armai Arief, Pengantar IImu dan Metodologi Pendidikan Agama Islam, Ciputat Pers,Jakarta, 2002

Bisri Mustofa, Menjadi Sehat Dengan Sholat, Optimus, Jogjakarta, 2007

Departemen Agama RI, AL-Qur'an dan Terjemahnya, Surya Cipta Aksara, Jakarta,2008

Departemen Pendidikan dan Kebudayaan RI, Kamus Besar Bahasa Indonesia, Edisi II, Cet ke 4,1995

Departemen Pendidikan Nasional, Pedoman Pembelajaran Di Taman Kanakkanak, Jakarta, 2006

Dr. Sa'id bin Ali Wahf Al-Qahthani, Syaikh Abdullah bin Abdurrahman Al-Jibrin, Tuntunan Sholat Bergambar, 2006

Dr. Wina Sanjaya, Strategi Pembelajaran Berorientasi Standart Proses Pendidikan

Hamzah B. Uno, Tugas Guru Dalam Pembelajaran Aspek yang Memengaruhi, (Jakarta Bumi Aksara)

Kunandar, Guru Profesional Implementasi Kurikulum KTSP dan Sukses dalam Sertifikasi Guru, Pt. Raja Grafundo

Misa Abdu, Al-khusyuk Fish Shalah wa Asraruhu, (terj) Jujuk Najibah Ardianingsih, Menjernihkan Batin Dengan Sholat khusyu' (Yogyakarta Mitra Pustaka, 2005) 